\title{
A PARADIGM SHIFT FOR THE SGLT2 INHIBITORS - TREATING THE HEART WITH ANTI-HYPERGLYCAEMIC DRUGS
}

\author{
ELISABETA BĂDILĂ ${ }^{1,2}$, ANA-MARIA BALAHURA ${ }^{1,2 *}$, MARILENA STOIAN ${ }^{1,3}$, DANIELA \\ BARTOS ${ }^{1,2}$, DRAGOȘ VINEREANU ${ }^{1,4}$ \\ ${ }^{I}$ Department of Internal Medicine, "Carol Davila” University of Medicine and Pharmacy, 37 Dionisie Lupu Street, 020021, \\ Bucharest, Romania \\ ${ }^{2}$ Department of Internal Medicine, Clinical Emergency Hospital Bucharest, 8 Floreasca Street, 014461, Bucharest, Romania \\ ${ }^{3}$ Department of Internal Medicine, "Dr. I. Cantacuzino” Clinical Hospital, 5-7 Ion Movilă Street, 030167, Bucharest, \\ Romania \\ ${ }^{3}$ Department of Cardiology, University and Emergency Hospital, 169 Splaiul Independenței, 050098, Bucharest, Romania
}

*corresponding author: ana-maria.balahura@umfcd.ro

Manuscript received: February 2021

\begin{abstract}
Sodium-glucose cotransporter-2 inhibitors (SGLT2i) are a newer class of anti-hyperglycaemic drugs that act by partially inhibiting glucose reabsorption from the renal filtrate and inducing glycosuria. However, they have several other benefits, independent of the glycaemic control. SGLT2i reduced major cardiovascular events, including new-onset heart failure, in patients with type 2 diabetes mellitus (T2DM), in large randomized clinical trials. These effects have been recently described in patients with HF with reduced ejection fraction, irrespective of their diabetic or glycated haemoglobin status, suggesting that their benefits are driven independently of their glucose lowering properties. This review summarizes the current evidence for their cardioprotective effects, and provides an overview of the possible mechanisms for the cardiovascular benefits. The alleged mechanisms that lead to improve cardiovascular outcome, even though still incompletely understood, include an association between improvement in cardiac pre- and after-load, partially explained by osmotic diuresis and natriuresis, prevention of cardiac remodelling, direct cardiac effects with improved cardiac energetics and ion handling, antiinflammatory effects, and anti-fibrotic effects. Therefore, in the latest years, both mechanistic insights, as well as major trials data, have repurposed SGLT2i usage from only anti-diabetic to potent HF treatment drugs, and new indications have been attributed to these compounds in HF guidelines.
\end{abstract}

\section{Rezumat}

Inhibitorii cotransportorului 2 sodiu - glucoză (SGLT2i) sunt o clasă relativ recentă de medicamente anti-hiperglicemice care acționează prin inhibarea parțială a reabsorbției glucozei din ultrafiltratul renal și inducerea glicozuriei. Cu toate acestea, ei au și alte beneficii, independente de controlul glicemic. SGLT2i au redus evenimentele cardiovasculare (CV) majore, inclusiv insuficiența cardiacă (IC) „,de novo”, la pacienții cu diabet zaharat de tip 2 (T2DM), în studiile clinice randomizate mari. Aceste efecte au fost descrise recent la pacienții cu IC cu fracție de ejecție redusă, indiferent de prezența sau absența T2DM sau de valorile hemoglobinei glicate, sugerând că beneficiile lor sunt determinate independent de proprietățile de reducere a glicemiei. Acest articol sumarizează dovezile actuale pentru efectele lor cardioprotectoare și oferă o imagine de ansamblu asupra posibilelor mecanisme implicate în inducerea beneficiilor CV. Presupusele mecanisme care conduc la îmbunătățirea prognosticului CV, chiar dacă sunt încă incomplet înțelese, includ o asociere între îmbunătătirea pre- și post-sarcinii ventriculare, explicată parțial prin diureza osmotică și natriureză, prevenirea remodelării cardiace, efecte cardiace directe cu îmbunătățirea energeticii cardiace și cineticii ionilor, efecte anti-inflamatorii și efecte anti-fibrotice. Prin urmare, în ultimii ani, atât cunoștințele fiziopatologice, cât și datele studiilor majore, au redirecționat utilizarea SGLT2i de la medicamente pur antidiabetice la medicamente pentru tratamentul IC, atribuindu-le noi indicații în ghidurile de IC.

Keywords: SGLT2 inhibitors, cardiovascular protection, heart failure

\section{Introduction}

Sodium-glucose cotransporter-2 inhibitors (SGLT2i), developed initially as a class of anti-hyperglycaemic drugs, have both glycaemic and non-glycaemic benefits. Recent advances in the understanding of the nonglycaemic effects of SGLT2i have shown cardiovascular $(\mathrm{CV})$ and renal protection, with potential benefits in heart failure (HF) [23, 25, 40, 51].
The last decade showed a paradigm shift in the use of glucose-lowering drugs in patients with diabetes and $\mathrm{CV}$ disease, mainly $\mathrm{HF}$. The initial principle in prescribing these drugs in patients with $\mathrm{HF}$ and $\mathrm{CV}$ disease was, for many years, safety (using glucose lowering drugs that do not increase CV events). The therapeutically approach of these patients further evolved aiming at efficacy rather than just safety, treating diabetic patients with HF with drugs that 
improve CV outcome along with their anti-hyperglycaemic effect. The latest years have revolutionized the use of these drugs with the repurposing to treat $\mathrm{HF}$, even in the absence of diabetes [23, 25].

Briefly, SGLT2 inhibitors act to reduce blood glucose by blocking its reabsorption in the kidneys leading to urinary glucose excretion, reduced blood glucose levels, and reduction of plasma volume and sodium load [31]. These effects are accompanied by other mechanisms that lead to $\mathrm{CV}$ and renal protection; thus, several mechanisms have been postulated, such as their favourable effects on blood pressure (BP) reduction, increasing diuresis/natriuresis, improving cardiac energy metabolism, preventing inflammation and decreasing oxidative stress, reducing hyperuricemia, inducing weight loss, inhibiting the sympathetic nervous system, preventing cardiac remodelling, preventing ischemia/ reperfusion injury, decreasing epicardial fat mass, increasing erythropoietin (EPO) levels, and improving vascular function [4, 8, 21, 22, 31, 37, 50, 55].

In this review, we provide an overview of the mechanism of action of these medication in type 2 diabetes mellitus (T2DM) and on the CV system. Meanwhile, we analyse the most relevant findings derived from recent randomized clinical trials, supporting the broadening of SGLT2i indication from glucose lowering therapy to cardiovascular protection in diabetic patients, and to HF treatment in diabetic and nondiabetic patients.

\section{SGLT2i and their mechanism of action (Figure 1)}

In the normal healthy adult, the kidney can filter and reabsorb approximately $180 \mathrm{~g}$ of glucose daily with virtually no glucose excreted in the urine. However, once the maximal limits of reabsorption are reached, the excess glucose starts to get excreted in the urine $[25,51]$. The SGLTs are a family of membrane proteins that are associated with the transport of glucose and ions over the brush-border membrane of proximal renal tubules and the intestinal epithelium [3]. These proteins are responsible for the first step of glucose reabsorption through the apical cell membrane via a secondary active-transport which is driven by the electrochemical sodium gradient between the tubular filtrate and the cell. This gradient requires active basolateral $\mathrm{Na}^{+}$removal by the $\mathrm{Na}^{+} / \mathrm{K}^{+}$-ATPase [35]. The second step takes place on the basolateral side where glucose exits the cells, due to its concentration gradient, and re-enters the bloodstream, via a facilitative transport (GLUT2), a member of another family of glucose transporter proteins (GLUT) [25].

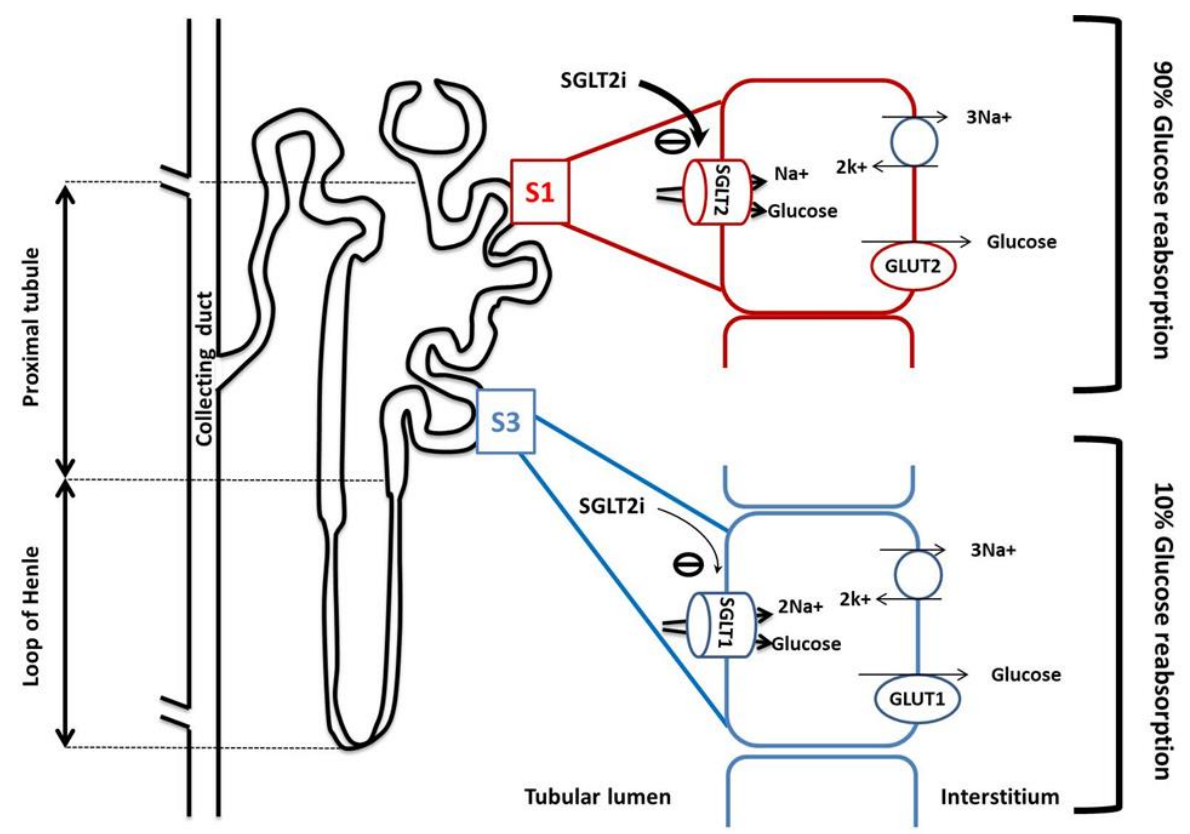

Figure 1.

Sodium glucose co-transporter (SGLT) and glucose handling in the kidney. SGLT2, found in the early part of the proximal tubule $(\mathrm{S} 1)$, accounts for $\sim 90 \%$ of whole kidney fractional glucose reabsorption. SGLT2 binds one sodium $\left(\mathrm{Na}^{+}\right)$molecule and one glucose molecule and transports them from the tubular lumen into the tubular cell. GLUT2 (glucose transporter 2) then pumps the glucose molecule into the interstitial fluid. SGLT1 in turn, located in the distal (S3) segment of the proximal tubule, is responsible for the remainder of $10 \%$ of whole kidney fractional glucose reabsorption, and transports $2 \mathrm{Na}^{+}$molecule and 1 glucose molecule from the tubular lumen into the tubular cell. GLUT1 then pumps the glucose molecules into the interstitial space. By inhibiting SGLT, the SGLT2 inhibition will result in glycosuria and natriuresis. The $\mathrm{Na}^{+} / \mathrm{K}^{+}$pump is responsible for the active transportation of $\mathrm{Na}^{+}$from the tubular cell into the interstitial space [3, 24, 34]. 
Several members of the SGLT family have been identified, however, SGLT1 and SGLT 2 are the main actors in glucose handling in the kidney and the gastrointestinal tract. SGLT2 is a high-capacity, low-affinity transporter found primarily in the kidney, in the early part of the proximal tubule (S1), and accounts for all glucose reabsorption in this segment and for $\sim 90 \%$ of whole kidney fractional glucose reabsorption [18, 48]. SGLT1 in turn is a low-capacity, high-affinity transporter which is located primarily in the gastrointestinal tract but is also found in the S3 segment of the proximal tubule. SGLT1 is responsible for the remainder of $10 \%$ of whole kidney fractional glucose reabsorption [51].

Hyperglycaemia increases the amount of glucose filtered in the kidneys along with an increase in the reabsorption capacity by $20 \%$ [48]. This is possible mainly by an increased expression of SGLT2 in the proximal tubule. As a consequence, the glycosuric and blood glucose lowering effects of SGLT2 inhibition become more potent in hyperglycaemic states, where SGLT2 is upregulated [6, 19, 42]. In turn, the risk of hypoglycaemia associated with SGLT2 inhibitors is low. This is a result of compensation by SGLT1 in the downstream S3 proximal tubule, which stops glucose excretion when the filtered glucose falls below the transport capacity of SGLT1 [48]. Moreover, SGLT2i leave the metabolic counter-regulation intact, increasing hepatic gluconeogenesis and plasma glucagon levels [28].

Glucose metabolism is a complex process and the SGLT protein family plays many roles. If the SGLT2 is the major acting transporter in the kidney, in the small intestine SGLT1 is a key player in the luminal uptake of dietary glucose. Similar to the kidney reabsorption, after glucose is taken up from the luminal part of the intestinal cell by SGLT1, it then exits through the basolateral membrane into the blood stream via GLUT2 [44]. This intestinal SGLT1 glucose uptake also modulates the secretion of incretins, including glucagon-like peptide-1 (GLP-1) and glucosedependent insulinotropic peptide (GIP). Moreover, in the distal intestinal segments it has been postulated that glucose is metabolized by the gut microbiome and transformed in short-chain fatty acids (SCFAs) which in turn will induce sustained release of GLP-1 [34, 57]. Therefore, SGLT1 inhibition results in both a direct reduction in glucose uptake and an indirect promotion of sustained release of glucose-lowering incretins [35].

The history of SGLTi starts with phlorizin which gave the drug class name of gliflozins. Phlorizin, a naturally occurring $O$-glucoside molecule, was discovered over 150 years ago and was subsequently found to increase urinary glucose excretion in healthy humans [7]. Despite its glucose lowering effect, phlorizin was not further pursued as an anti-diabetic drug. Firstly, because phlorizin is quickly metabolized in the intestinal tract by $\beta$ glucosidase upon oral administration. Secondly, it acts as a nonselective SGLT inhibitor; therefore, it also inhibits SGLT1 and leads to gastrointestinal side effects, such as diarrhoea and dehydration [20, 25].

Main pharmacokinetic parameters of SGLT2 inhibitors with reported CV outcome data. OD - once daily [39, 53]

\begin{tabular}{|l|c|c|c|c|}
\hline & CANAGLIFLOZIN & DAPAGLIFLOZIN & EMPAGLIFLOZIN & ERTUGLIFLOZIN \\
\hline Maximum daily dosage & $300 \mathrm{mg}$ OD & $10 \mathrm{mg}$ OD & $25 \mathrm{mg}$ OD & $15 \mathrm{mg}$ OD \\
\hline Half-life (hours) & $11-13$ & $12.2-12.9$ & 12.4 & 16.6 \\
\hline Oral bioavailability & $65 \%$ & $78 \%$ & $60 \%$ & $100 \%$ \\
\hline Metabolism and elimination & $\begin{array}{c}\text { Extensive hepatic } \\
\text { glucuronidation }\end{array}$ & $\begin{array}{c}\text { Extensive hepatic } \\
\text { glucuronidation }\end{array}$ & $\begin{array}{c}\text { Extensive hepatic } \\
\text { glucuronidation }\end{array}$ & $\begin{array}{c}\text { Extensive hepatic } \\
\text { glucuronidation }\end{array}$ \\
\hline Elimination & $\begin{array}{c}\text { Renal excretion as } \\
\text { inactive metabolite } \\
(<1 \% \text { elimination as } \\
\text { unchanged drug) }\end{array}$ & $\begin{array}{c}\text { Renal excretion as } \\
\text { inactive metabolite } \\
(<2 \% \text { elimination as } \\
\text { unchanged drug) }\end{array}$ & $\begin{array}{c}\text { Renal excretion } \\
(28 \% \text { elimination as } \\
\text { unchanged drug) }\end{array}$ & $\begin{array}{c}\text { Renal excretion } \\
\text { predominantly as } \\
\text { inactive metabolite }\end{array}$ \\
\hline $\begin{array}{l}\text { SGLT2 selectivity versus } \\
\text { SGLT1 (SGLT2:SGLT1) }\end{array}$ & $250: 1$ & $1200: 1$ & $2500: 1$ & $2000: 1$ \\
\hline
\end{tabular}

To overcome these problems, further research led to the identification of the novel C-glucoside-containing selective SGLT2i such as dapagliflozin, canagliflozin, empagliflozin and ertugliflozin. This C-glycosylation makes these molecules resistant to hydrolysis by $\beta$ glucosidases, increasing their half-life. Several differences exist between these drugs including their selectivity for the SGLT2 over SGLT1. For instance, it can range from 250:1 for canagliflozin to $\sim 2500: 1$ for empagliflozin $[20,25,39,51,53]$. The main pharmacokinetic properties of SGLT2i are summarized in Table I.

\section{SGLT2i and cardioprotection in patients with T2DM - clinical data}

Currently, there are four SGLT2i that are approved for T2DM treatment and have been investigated in large cardiovascular outcomes trials in diabetic patients: dapagliflozin, empagliflozin, ertugliflozin and canagliflozin. The summary of these trials characteristics and results are summarized in Table II. 
Table II

Comparison of main population characteristics and results between CV outcome SGLT2i trials

\begin{tabular}{|c|c|c|c|c|}
\hline & CANAGLIFLOZIN & DAPAGLIFLOZIN & EMPAGLIFLOZIN & ERTUGLIFLOZIN \\
\hline \multicolumn{5}{|c|}{ CVOT in patients with T2DM } \\
\hline $\begin{array}{l}\begin{array}{l}\text { Trial, year of } \\
\text { publication }\end{array} \\
\end{array}$ & CANVAS, $2017[30]$ & $\begin{array}{c}\text { DECLARE TIMI 58, } \\
2019[54]\end{array}$ & $\begin{array}{c}\text { EMPA-REG Outcome, } \\
2015 \text { [59] }\end{array}$ & $\begin{array}{c}\text { VERTIS - CV, } 2020 \\
\text { [5] }\end{array}$ \\
\hline Number of patients & 10,142 & 17,160 & 7020 & 8238 \\
\hline Population & $\begin{array}{c}\text { T2DM pts with } \\
\text { established ASCVD } \\
(72.2 \%) \text { and pts at risk } \\
\text { for ASCVD }\end{array}$ & $\begin{array}{l}\text { T2DM pts with } \\
\text { established ASCVD } \\
(40.6 \%) \text { and pts at risk for } \\
\text { ASCVD }\end{array}$ & $\begin{array}{c}\text { T2DM pts with } \\
\text { established ASCVD }\end{array}$ & $\begin{array}{c}\text { T2DM pts with } \\
\text { established ASCVD }\end{array}$ \\
\hline & HF $14.4 \%$ & $\begin{array}{l}\text { HFrEF }-3.9 \% \\
\text { HFpEF }-7.7 \%\end{array}$ & HF $10.1 \%$ & HF $23.9 \%$ \\
\hline Follow up & 3.6 years & 4.2 years & 3.1 years & 3.5 years \\
\hline Dosage & 100 or $300 \mathrm{mg}$ OD & $10 \mathrm{mg}$ OD & 10 or $25 \mathrm{mg}$ OD & 5 or $15 \mathrm{mg}$ OD \\
\hline 3P-MACE vs. placebo & $\begin{array}{c}\text { HR } 0.86 \\
95 \% \text { CI } 0.75-0.97\end{array}$ & $\begin{array}{c}\text { HR } 0.93 \\
95 \% \text { CI } 0.84-1.03\end{array}$ & $\begin{array}{c}\text { HR } 0.86 \\
95 \% \text { CI } 0.74-0.99\end{array}$ & $\begin{array}{c}\text { HR } 0.97 \\
95 \% \text { CI } 0.85-1.11\end{array}$ \\
\hline CV death & $\begin{array}{c}\text { HR } 0.87 \\
95 \% \text { CI } 0.72-1.06\end{array}$ & $\begin{array}{c}\text { HR } 0.98 \\
95 \% \text { CI } 0.82-1.17\end{array}$ & $\begin{array}{c}\text { HR } 0.62 \\
95 \% \text { CI } 0.49-0.77\end{array}$ & $\begin{array}{c}\text { HR } 0.92 \\
95 \% \text { CI } 0.77-1.11\end{array}$ \\
\hline Non-fatal MI & $\begin{array}{c}\text { HR } 0.85 \\
95 \% \text { CI } 0.69-1.05\end{array}$ & $\begin{array}{c}\text { HR } 0.89 \\
95 \% \text { CI } 0.77-1.01\end{array}$ & $\begin{array}{c}\text { HR } 0.87 \\
95 \% \text { CI } 0.7-1.09\end{array}$ & $\begin{array}{c}\text { HR } 1.00 \\
95 \% \text { CI } 0.86-1.27\end{array}$ \\
\hline Non-fatal stroke & $\begin{array}{c}\text { HR } 0.90 \\
95 \% \text { CI } 0.71-1.15\end{array}$ & $\begin{array}{c}\text { HR } 1.01 \\
95 \% \text { CI } 0.84-1.21\end{array}$ & $\begin{array}{c}\text { HR } 1.24 \\
95 \% \text { CI } 0.92-1.67\end{array}$ & $\begin{array}{c}\text { HR } 1.00 \\
95 \% \text { CI } 0.76-1.32\end{array}$ \\
\hline All-cause death & $\begin{array}{c}\text { HR } 0.87 \\
95 \% \text { CI } 0.74-1.01\end{array}$ & $\begin{array}{c}\text { HR } 0.93 \\
95 \% \text { CI } 0.82-1.04\end{array}$ & $\begin{array}{c}\text { HR } 0.68 \\
95 \% \text { CI } 0.57-0.82\end{array}$ & - \\
\hline HF Hospitalization & $\begin{array}{c}\text { HR } 0.67 \\
95 \% \text { CI } 0.52-0.87\end{array}$ & $\begin{array}{c}\text { HR } 0.73 \\
95 \% \text { CI } 0.61-0.88\end{array}$ & $\begin{array}{c}\text { HR } 0.65 \\
95 \% \text { CI } 0.50-0.85\end{array}$ & $\begin{array}{c}\text { HR } 0.70 \\
95 \% \text { CI } 0.54-0.90\end{array}$ \\
\hline $\begin{array}{l}\text { Composite renal } \\
\text { outcome }^{1}\end{array}$ & $\begin{array}{c}\text { HR } 0.53 \\
95 \% \text { CI } 0.33-0.84\end{array}$ & $\begin{array}{c}\text { HR } 0.53 \\
95 \% \text { CI } 0.43-0.66\end{array}$ & $\begin{array}{c}\text { HR } 0.61 \\
95 \% \text { CI } 0.53-0.70\end{array}$ & $\begin{array}{c}\text { HR } 0.81 \\
95 \% \text { CI } 0.63-1.04\end{array}$ \\
\hline Adverse events & \begin{tabular}{|c|} 
Higher risk of GTI, \\
amputation, fracture \\
and volume depletion
\end{tabular} & $\begin{array}{c}\text { Higher risk of GTI, AKI, } \\
\text { DKA, hypoglycaemia }\end{array}$ & $\begin{array}{c}\text { Higher risk of UTI, GTI, } \\
\text { AKI }\end{array}$ & $\begin{array}{c}\text { Higher risk of UTI, } \\
\text { GTI }\end{array}$ \\
\hline \multicolumn{5}{|c|}{ CVOT in patients WITH OR WITHOUT T2DM } \\
\hline $\begin{array}{l}\text { Trial, year of } \\
\text { publication }\end{array}$ & & DAPA-HF, 2019 [27] & \begin{tabular}{|c|} 
EMPEROR -Reduced, \\
$2020[32]$
\end{tabular} & \\
\hline Number of patients & & 4744 & 3730 & \\
\hline Population & & \begin{tabular}{|c|} 
LVEF $<40 \%$ \\
NYHA II-IV \\
Increased NT proBNP \\
GFR $\geq 20 \mathrm{~mL} / \mathrm{min} / 1.73 \mathrm{~m}^{2}$
\end{tabular} & $\begin{array}{c}\text { LVEF }<40 \% \\
\text { NYHA II-IV } \\
\text { Increased NT proBNP } \\
\text { GFR } \geq 30 \mathrm{~mL} / \mathrm{min} / 1.73 \mathrm{~m}^{2}\end{array}$ & \\
\hline - Non-T2DM & & $58.2 \%$ & $50.2 \%$ & \\
\hline - Mean age (years) & & 66.5 & 66.5 & \\
\hline - Mean LVEF & & $30.9 \%$ & $27.2 \%$ & \\
\hline - NT proBNP (median) & & $1446 \mathrm{pg} / \mathrm{mL}$ & $1926 \mathrm{pg} / \mathrm{mL}$ & \\
\hline Follow up & & 18.2 months & 16 months & \\
\hline Dosage & & $10 \mathrm{mg}$ OD & $10 \mathrm{mg}$ OD & \\
\hline Primary endpoint ${ }^{2, \#}$ & & $\begin{array}{c}\text { HR } 0.74 \\
95 \% \text { CI } 0.65-0.85\end{array}$ & $\begin{array}{c}\text { HR } 0.75 \\
95 \% \text { CI } 0.65-0.86\end{array}$ & \\
\hline CV death & & $\begin{array}{c}\text { HR } 0.82 \\
95 \% \text { CI } 0.69-0.98\end{array}$ & $\begin{array}{c}\text { HR } 0.92 \\
95 \% \text { CI } 0.75-1.12\end{array}$ & \\
\hline All-cause death & & $\begin{array}{c}\text { HR } 0.83 \\
95 \% \text { CI } 0.71-0.97\end{array}$ & $\begin{array}{c}\text { HR } 0.92 \\
95 \% \text { CI } 0.77-1.10\end{array}$ & \\
\hline HF Hospitalization & & $\begin{array}{c}\text { HR } 0.70 \\
95 \% \text { CI } 0.59-0.83\end{array}$ & $\begin{array}{c}\text { HR } 0.69 \\
95 \% \text { CI } 0.59-0.81\end{array}$ & \\
\hline $\begin{array}{l}\text { Composite renal } \\
\text { outcome }^{3}\end{array}$ & & $\begin{array}{c}\text { HR } 0.71 \\
95 \% \text { CI } 0.44-1.16\end{array}$ & $\begin{array}{c}\text { HR } 0.5 \\
95 \% \text { CI } 0.32-0.77\end{array}$ & \\
\hline Adverse events & & No difference vs placebo & Higher risk of GTI & \\
\hline \multicolumn{5}{|c|}{$\begin{array}{l}\text { AKI - acute kidney injury; ASCVD - atherosclerotic cardiovascular (CV) disease; CI - confidence interval; DKA - diabetic ketoacidosis; } \\
\text { GTI - genital tract infections; HF - heart failure; HFpEF - HF with preserved ejection fraction; HFrEF - HF with reduced EF; } \\
\text { HR - hazard ratio; 3P-MACE - } 3 \text { point major adverse cardiac events (death from CV causes, nonfatal myocardial infarction (MI), or nonfatal } \\
\text { stroke); OD - once daily; T2DM - type } 2 \text { diabetes mellitus; UTI - urinary tract infections } \\
\text { '1Composite renal outcome definition. }\end{array}$} \\
\hline
\end{tabular}


In CANVAS: $40 \%$ reduction in GFR (glomerular filtration rate) sustained for at least 2 measurements, the need for renal replacement therapy or death from renal causes.

In DECLARE TIMI-58: $\geq 40 \%$ decrease in estimated GFR to $<60 \mathrm{~mL}$ per minute per $1.73 \mathrm{~m}^{2}$ of body-surface area, new end-stage renal disease, or death from renal or CV causes.

In EMPA-REG outcome: need for renal replacement therapy or a profound reduction in the estimated GFR.

In VERTIS CV: death from renal causes, renal replacement therapy, or doubling of the serum creatinine level.

${ }^{2}$ The primary outcome for EMPEROR-Reduced was a composite of CV death or hospitalization for worsening HF; for DAPA-HF was composite of death from CV causes or worsening HF.

${ }^{3}$ The composite kidney outcome for EMPEROR-Reduced was need for renal replacement therapy, a sustained reduction of $\geq 40 \%$ in the eGFR or a sustained eGFR $<15 \mathrm{~mL}$ per min per $1.73^{2}$ in patients with a baseline eGFR of $\geq 30 \mathrm{~mL}$ per min per $1.73^{2}$ or a sustained eGFR $<10 \mathrm{~mL}$ per min per $1.73^{2}$ in patients with a baseline eGFR of $<20 \mathrm{~mL}$ per $\min$ per $1.73^{2}$; for DAPA-HF was a sustained decline in the eGFR of $\geq 50 \%$ for $\geq 28$ days, end-stage kidney disease (defined as $\geq 28$ days of eGFR $<15 \mathrm{~mL}$ per min per $1.73^{2}$, sustained dialysis, or transplantation), or kidney death and death from any cause.

${ }^{\#}$ Cardiovascular outcomes reported for DAPA-HF and EMPEROR reduced were not different between patients with or without T2DM

The first trial published was EMPA-REG OUTCOME (empagliflozin Cardiovascular Outcome Event Trial in Type 2 Diabetes Mellitus Patients) which included a total of 7020 patients with established CV disease and T2DM. They received OD empagliflozin (10 mg or $15 \mathrm{mg}$ ) versus placebo and were followed for 3.1 years. The trial reached its primary outcome reporting a $14 \%$ relative risk (RR) reduction in the 3 point major adverse CV events (3P - MACE), including $\mathrm{CV}$ death, nonfatal myocardial infarction (MI) or nonfatal stroke $(\mathrm{p}<0.001$ for non-inferiority and $\mathrm{p}=0.04$ for superiority), for the intervention group. empagliflozin resulted also in a $38 \% \mathrm{RR}$ reduction of $\mathrm{CV}$ death, $35 \% \mathrm{RR}$ reduction of hospitalization for $\mathrm{HF}$ and $32 \%$ $\mathrm{RR}$ reduction of death from any cause. empagliflozin increased, however, the rates of genital infections [60]. In 2017, results of the CANVAS trial (Canagliflozin and Cardiovascular and Renal Events in Type 2 Diabetes) were published. The CANVAS trial recruited 10,142 participants with T2DM and high CV risk which were randomly assigned to receive canagliflozin or placebo. They were subsequently followed for a mean of 3.6 years. Canagliflozin resulted in a $14.4 \%$ $\mathrm{RR}$ in the 3P-MACE (death from CV causes, nonfatal MI, or nonfatal stroke) ( $\mathrm{p}$ for non-inferiority < 0.001 and $p$ for superiority $=0.02$ ). However, a higher risk of amputation, primarily at the toe and metatarsal level, was observed [30]. The CREDENCE trial (Canagliflozin and Renal Outcomes in Type 2 Diabetes and Nephropathy) evaluated the impact of canagliflozin primarily on chronic kidney disease (CKD). It included 4401 patients with T2DM and CKD with albuminuria, randomized to receive canagliflozin $100 \mathrm{mg}$ OD or placebo. Canagliflozin resulted in a RR of $32 \%$ for end-stage CKD ( $p=0.002), 20 \%$ for CV death, MI, or stroke $(p=0.01)$, and $39 \%$ for hospitalization for HF ( $p<0.001)$. In contrast to the CANVAS program, there were no significant differences in rates of amputation or fracture between the intervention and the placebo group [33].

Dapagliflozin was tested for its $\mathrm{CV}$ outcomes in T2DM patients in DECLARE TIMI 58 (Dapagliflozin Effect on Cardiovascular Events). The study randomized 17,160 patients, including 10,186 without atherosclerotic $\mathrm{CV}$ disease, to either dapagliflozin $10 \mathrm{mg}$ OD or placebo. The follow-up period was 4.2 years. The 3P - MACE (death from CV causes, nonfatal MI, or nonfatal stroke) was not significantly different in the dapagliflozin group versus placebo. However, it did result in a $13 \% \mathrm{RR}$ of $\mathrm{CV}$ death or hospitalization for HF ( $p=0.005)$, driven mainly by the lower rate of HF hospitalization (RR of $27 \%$ ). In terms of adverse effects, dapagliflozin induced higher rates of diabetic ketoacidosis $(0.3 \%$ vs. $0.1 \%, \mathrm{p}=0.02)$ and genital infections $(0.9 \%$ vs. $0.1 \%, \mathrm{p}<0.001)$ [54]. Cardiovascular outcome for ertugliflozin was published in the VERTIS CV (Cardiovascular Outcomes with ertugliflozin in Type 2 Diabetes) trial in 2020. A total of 8246 patients with T2DM and atherosclerotic CV disease were randomized to ertugliflozin $(5 \mathrm{mg}$ or $15 \mathrm{mg}$ OD) or placebo, and were followed for a mean of 3.5 years. There were no differences in the $3 \mathrm{P}$ MACE between the intervention and placebo group ( $\mathrm{p}$ for non-inferiority $<0.001$ ), and no differences in the secondary endpoint of death from $\mathrm{CV}$ causes or HF hospitalization. Moreover, ertugliflozin did not influence the renal endpoint of death from renal causes, renal replacement therapy, or doubling of the serum creatinine level compared to placebo [5]. These trials reported inconsistencies in CV outcomes that are not explained only by differences in the pharmacological properties of the individual drugs. For instance, empagliflozin has the highest SGLT2 selectivity while canagliflozin the lowest. However, both trials investigating these 2 SGLT2i reported superiority in terms of CV outcome. Differences in the $\mathrm{CV}$ risk of the studied population might be the explanation for the inconsistencies in $\mathrm{CV}$ outcome results. While EMPA-REG OUTCOME and VERTIS $\mathrm{CV}$ trials included only patients with established $\mathrm{CV}$ disease, DECLARE TIMI 58 and CANVAS trials included patients at risk of $\mathrm{CV}$ as well. In fact, DECLARE TIMI 58 trial reported the lowest rate of CV events per 1000 patients-years and this might introduce some bias in the statistical analysis, resulting in non-significant differences between the intervention and placebo group $[5,30,54,60]$.

One meta-analysis evaluating 34,322 patients from the DECLARE TIMI 58, CANVAS, and EMPA-REG OUTCOME trials, from which $60.2 \%$ had established 
atherosclerotic $\mathrm{CV}$ disease (ASCVD), showed that SGLT2i have, as the most important and consistent effect, the reduction in RR of HF hospitalisation $(31 \%)$ and of progression of renal disease $(45 \%)$, irrespective of the presence or absence of established ASCVD. However, their effect on the 3P-MACE was more modest, with $11 \%$ statistically significant reduction in RR which was apparent only in patients with established ASCVD, whereas no effect was observed in patients without ASCVD [59]. Therefore, it appears that the effect of SGLT2i on selected CV outcomes depends on the patient population in which they are used.

\section{SGLT2i mechanisms of cardioprotection (Figure 2)}

SGLT2i, as shown above, have been initially developed as glucose lowering drugs. However, extensive data showed that these agents have a favourable metabolic profile and significantly reduce atherosclerotic events, hospitalization for HF, CV and total mortality, and progression of CKD [50]. Moreover, their benefits, especially related to $\mathrm{HF}$ and $\mathrm{CKD}$ treatment, have been shown to be present in patients without diabetes as well [27, 32].

These positive CV outcomes cannot be solely attributed to the SGLT2i glucose lowering effects as shown in the DAPA-HF and EMPEROR-Reduced trials, where their benefits on HFrEF were independent of the presence or absence of T2DM and the glycaemic status [27, 32]. Although the precise mechanisms are currently incompletely clarified, in recent years various theories have been put forward to explain their $\mathrm{CV}$ and renal beneficial effects $[31,50]$.

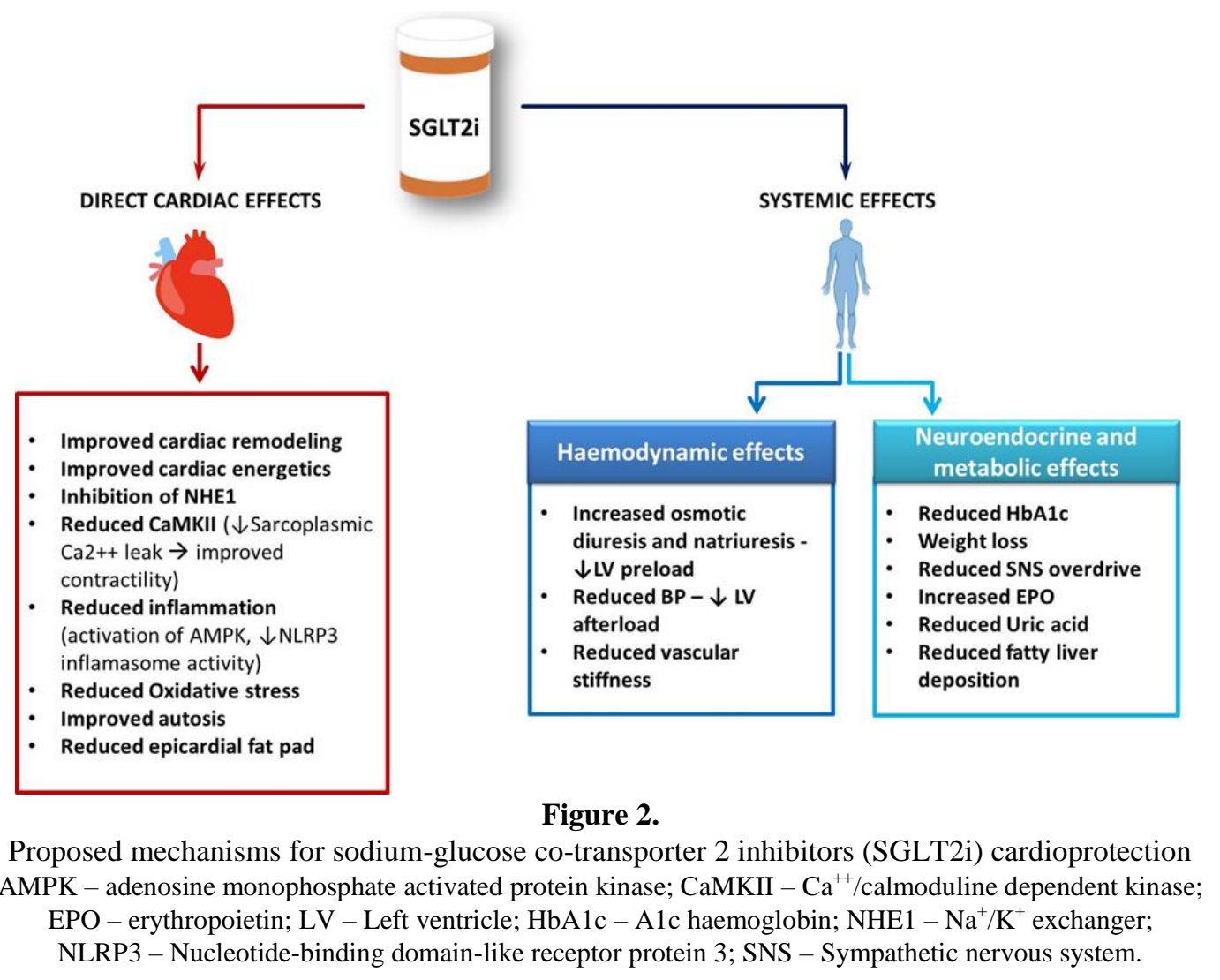

SGLT2i - haemodynamic effects. SGLT2 inhibition in the proximal tubule results in natriuresis and glycosuria which leads to osmotic diuresis. This will in turn improve ventricular loading conditions due to reduction in preload. The diuretic effect of SGLTi is, however, different from that of the conventional diuretics (thiazides and loop diuretics). SGLT2i reduce to a greater extent the interstitial oedema with little or no effect on the intravascular volume, as compared with classical diuretics that will impact mainly on intravascular volume [9].
Another mechanism that improves cardiac dynamics trough reduction of cardiac afterload is SGLT2i induced lowering of arterial blood pressure [15]. Although not fully understood, the antihypertensive effect of SGLT2i is probably driven by several mechanisms which include increased natriuresis and diuresis, improved endothelial function and aortic stiffness, potential vasodilation through voltage-gated $\mathrm{K}^{+}$channels and $\mathrm{G}$ protein kinase and loss of body weight [43, 45]. One additional mechanism might be related to the salt sensitiveness of some form of hypertension. Indeed, in a prospective double blind, placebo controlled trial, 
SGLT2 inhibition with dapagliflozin resulted in a significant decrease in tissue sodium content of the skin along with reduced body weight and improved BP [14].

The synergistic effect of decreased LV preload and afterload induced by SGLT2i can be one factor leading to favourable cardiac remodelling and, as a consequence, a mechanism for reduced HF adverse events. In the Studies of Empagliflozin and Its Cardiovascular, Renal and Metabolic Effects in Patients with Diabetes Mellitus, or Prediabetes, and Heart Failure - SUGARDM-HF trial, empagliflozin reduced left ventricular (LV) volumes in patients with $\mathrm{HFrEF}$ (HF with reduced ejection fraction) and T2DM or prediabetes [21]. A reduction in LV mass, measured by cardiac magnetic resonance imaging (CMR), was seen with empagliflozin in patients with T2DM and coronary artery disease in the EMPA-HEART CardioLink-6 Randomized Clinical Trial [49]. In the DAPA-LVH trial, dapagliflozin treatment resulted in a significant reduction in $\mathrm{LV}$ mass (as assessed by MRI) in patients with LV hypertrophy and T2DM [4].

There have been consisting evidence of an increase in haematocrit with SGLT2 $i$ and an analysis from the EMPA-REG OUTCOME trial suggested that the observed increase in haematocrit and haemoglobin levels could explain part of the risk reduction in $\mathrm{CV}$ death by empagliflozin [11]. The increased haematocrit levels seen early after the initiation of SGLT2i and maintained during the treatment have been at least partially attributed to haemoconcentration due to diuresis and extravascular fluid depletion. However, treatment with SGLT2i also induce an increase in erythropoietin (EPO) concentration and reticulocyte count, which could be an additional mechanism for the increase in haematocrit and haemoglobin values [26]. Haematocrit elevation leads to increase tissue oxygen supply to the heart with resultant improvement in cardiac function. However, increased EPO levels have also favourable effects on the mitochondrial function of cardiomyocytes, cell proliferation and inflammation, and angiogenesis [31].

SGLT2i - cardiac metabolism and bioenergetics. The healthy heart metabolism relies on substrate flexibility which allows it to switch from one source of energy to another, depending on cardiac workload and metabolite availability. However, the main energy substrate remain fatty acids, followed by glucose and, to a smaller degree, ketones [8]. In disease states of the myocardium there is an altered energy metabolism with carbohydrate metabolism becoming the main source of energy and reducing utilization of fatty acids [22]. SGLT2i have been shown to improve cardiac energetics in HF by increasing circulating ketone levels, secondary to mobilizing adipose tissue fatty acids, which are then used by the liver for ketogenesis. This ketones act as a "supplement" of increasing fuel supply to the failing heart [22]. The beneficial effects of increasing ketone levels by SGLT2i were demonstrated in a non-diabetic ischemia animal model in which the administration of empagliflozin resulted in reduced LV remodelling and improved LV systolic function by turning myocardial fuel metabolism away from the low-yield energyproducing glucose metabolism toward ketogenesis which improves myocardial energy production [36]. SGLT2 $i$ - changes in the ion homeostasis of the myocardium. The myocardial $\mathrm{Na}^{+} / \mathrm{H}^{+}$exchanger (NHE) 1 isoform acts as a major mechanism for $\mathrm{pH}$ regulation during normal physiological processes, but mainly during ischaemia and early reperfusion [16]. Stimulation of NHE1 leads to an increase in cytosolic $\mathrm{Na}^{+}$and calcium and, therefore, it has been involved in the physiopathology of HF by promoting cell damage. Inhibition of NHE1 may lead to cardiac protection and has been recently shown that empagliflozin leads to inhibition of NHE, and determines a reduction of intracellular calcium and $\mathrm{Na}^{+}$while increasing the calcium supply to the mitochondria. However, it remains unclear how SGLT2i inhibit NHE1 as SGLT2 have not been found in the heart [2].

Activity of sarcoplasmic endoplasmic reticulum $\mathrm{Ca}^{2+}$ ATPase (SERCA2a) is modulated by SGLT2i. SERCA2a activity controls the contractility and relaxation of the heart through $\mathrm{Ca}^{2+}$ handling, affecting cardiac function. This ATPase is down-regulated in failing hearts. In animal models, administration of empagliflozin or dapagliflozin resulted in increased SERCA2a activity, which might contribute to the cardioprotective mechanism of SGLT2i.

Overexpression and activation of $\mathrm{Ca}^{2+} /$ calmodulindependent protein kinase II (CaMKII) has been suggested as another possible cardioprotective mechanism of SGLT2i. CaMKII are known mechanisms in the pathophysiology of $\mathrm{HF}$, leading to contractile dysfunction and arrhythmias by increasing diastolic $\mathrm{Ca}^{2+}$ leak from the sarcoplasmic reticulum (SR) and reducing SR $\mathrm{Ca}^{2+}$ load [11]. In isolated ventricular cardiomyocytes, empagliflozin reduced CaMKII activity [29].

SGLT2i - effects against inflammation, fibrosis, and apoptosis. Inflammation and fibrosis are key pathophysiological components of HF progression. SGLT2i have been shown in animal models to influence various inflammatory and profibrotic pathways that can lead to cardioprotective effects, such as reduction in the activation of the Nucleotide-Binding Domain-Like Receptor Protein 3 (NLRP3) inflammasome, reduction of macrophage infiltration, increased AMP activated protein kinase (AMPK) signalling pathways and blockage of the transforming growth factor (TGF- $\beta$ ) $[29,46$, 47, 56].

Autophagic cell death is a complex process in response to several factors, including cellular stress, ischemic injury or energy deprivation. Reduced activation of autophagy or excessive autophagy may both be harmful. In an animal model, empagliflozin showed a capacity to regulate and optimize the autophagy mechanism [13]. 
SGLT2i seems to influence the epicardial fat (EPF). Dapagliflozin significantly reduced the epicardial fat, as assessed by echocardiography, independent from body weight reduction [10]. Similar results were obtained with canagliflozine [37]. The epicardial fat pad has been involved in arrhythmogenesis and HF pathophysiology and, therefore, the effect exhibited by SGLT2 $i$ adds to their cardioprotective mechanism [31, 55].

SGLT2 $i$ and additional metabolic effects. SGLT2i have proven to induce a more favourable metabolic profile by inducing plasma glucose reductions, lower BP and body weight, and changes in the lipid profile [50]. Moreover, their metabolic benefits are reflected also in their hepatoprotective effect in non-alcoholic fatty liver disease (NAFLD) by reducing liver fat deposition in patients with T2DM [38]. Therefore, SGLT2 $\mathrm{i}$ have the potential to improve cardiometabolic risk in T2DM patients. Meanwhile, SGLT2i have a uricosuric effect reducing plasma uric acid levels by approximately $15 \%$ [55]. This mechanism might have an additional beneficial cardioprotective effect, since level of plasma uric acid has been proven to be an independent marker for adverse prognosis in HF [17].

\section{Repurposing SGLT2i}

After discovery of SGLT2i CV benefits in patients with T2DM, mainly in HF, a new research direction has developed to answer the question whether these drugs can be repurposed as an HF medication, even in patients without diabetes.

The first trial reporting on the potential benefits of SGLT2 $i$ in HFrEF, in both T2DM and nondiabetic patients, was the DAPA-HF, published in 2019 [27]. In this trial, 4744 patients (45\% with T2DM), with HFrEF (LV ejection fraction < 40\%) and increased NT-proBNP were enrolled and followed for a mean duration of 18.2 months. They were randomized to receive either dapagliflozin $10 \mathrm{mg}$ OD or placebo, in addition to the standard HF therapy. Patients with an estimated GFR $<30 \mathrm{~mL} / \mathrm{min} / 1.73 \mathrm{~m}^{2}$, symptomatic hypotension or systolic BP $<95 \mathrm{mmHg}$, or T1DM were excluded. The study met its primary outcome, reporting a statistically significant reduction in the composite of worsening HF and CV death by $26 \%$ $(\mathrm{p}<0.001)$. The primary outcome occurred in 386 $(16.3 \%)$ patients in the dapagliflozin group and in $502(21.2 \%)$ in the placebo group (hazard ratio 0.74; 95\% CI: 0.65 - 0.85). In the dapagliflozin arm, 231 $(9.7 \%)$ patients were hospitalized for worsening HF compared to $318(13.4 \%)$ in the placebo arm (hazard ratio $0.70 ; 95 \%$ CI: $0.59-0.83)$. Death from CV cause was observed in $227(9.6 \%)$ patients who received dapagliflozin and in $273(11.5 \%)$ who received placebo (hazard ratio 0.82 ; 95\% CI: 0.69 - 0.98). Death from any cause occurred in $276(11.6 \%)$ patients in the dapagliflozin group and in $329(13.9 \%)$ in the placebo group (hazard ratio 0.83 ; 95\% CI: $0.71-0.97$ ). An important finding was that the results did not differ between diabetic and non-diabetic patients. Moreover, there were no differences in adverse events between the 2 groups.

In 2020, another trial has reported the effects of empagliflozin in patients with HFrEF with or without diabetes [32]. The EMPEROR-Reduced trial recruited 3730 patients (49\% with T2DM), with symptomatic $\mathrm{HF}$ ranging from NYHA class II to IV, LV ejection fraction under $40 \%$, and increased NT-proBNP. These patients were randomized to receive empagliflozin $10 \mathrm{mg}$ OD or placebo, in addition to standard HF therapy, and were followed for a period of 16 months. The study met its primary outcome reporting a statistically significant $25 \%$ reduction in the composite of $\mathrm{CV}$ death or hospitalization for worsening HF. The primary outcome occurred in $361(19.4 \%)$ patients of the empagliflozin group and in $462(24.7 \%)$ in the placebo group (hazard ratio $0.75 ; 95 \%$ CI 0.65 - 0.86). In the empagliflozin arm, $246(13.2 \%)$ patients were hospitalized for HF compared to $342(18.3 \%)$ in the placebo arm (hazard ratio 0.69; 95\% CI: 0.59 - 0.81). Death from CV cause was observed in 187 (10.0\%) patients who received empagiflozin and in $202(10.8 \%)$ who received placebo (hazard ratio $0.92 ; 95 \% \mathrm{CI}$ : $0.75-1.12$ ). Death from any cause occurred in 249 $(13.4 \%)$ patients in the empagliflozin group and in $266(14.2 \%)$ in the placebo group (hazard ratio 0.92; 95\% CI: 0.77 - 1.10). Moreover, there was a significant reduction in the secondary endpoints, with $30 \%$ for HF hospitalization ( $\mathrm{p}<0.001$ ). As in DAPA-HF with dapagliflozin, empagliflozin effect on outcomes was consistent in patients regardless of the presence or absence of T2DM. Another beneficial effect encountered was the slowing of the annual rate of decline in renal function (assessed as a slope of the estimated GFR analysed on the basis of on-treatment data with a random coefficient model) in the empagliflozin group compared with the placebo group.

Both DAPA-HF and EMPEROR-Reduced trials have reached their primary and secondary endpoints showing their favourable influence on $\mathrm{CV}$ outcome in both diabetic and nondiabetic patients. However, even though they were not formally tested for significance, both studies analysed the two components of the primary outcome separately. Thus, in DAPA-HF, the hazard ratio (HR) for CV death was 0.82 (95\% CI: 0.69 0.98) which is significant, whereas in EMPERORReduced the HR for CV death was 0.92 (95\% CI: $0.75-1.12$ ), a result that is not nominally significant $[27,32]$. This difference on CV death between the two drugs is rather debatable, since in the EMPERORReduced trial, the enrolled patients had a more severe $\mathrm{HF}$, with a lower mean LV ejection fraction, by comparison with DAPA-HF trial, suggesting that these drugs might be less effective on more advanced $\mathrm{HF}$ 
[12]. A meta-analysis including both these trials showed a significant $31 \%$ (hazard ratio 0.69; 95\% CI: 0.62 - 0.78; $\mathrm{p}<0.0001)$ reduction in first HF hospitalization, a $26 \%$ reduction in the combined risk of $\mathrm{CV}$ death or first $\mathrm{HF}$ hospitalisation (hazard ratio $0.74 ; 95 \% \mathrm{CI}$ : $0.68-0.82 ; \mathrm{p}<0.0001$ ), a $25 \%$ reduction in the combined risk of $\mathrm{CV}$ death and $\mathrm{HF}$ recurrent hospitalisations (hazard ratio 0.75; 95\% CI: 0.68 - 0.84; $\mathrm{p}<0.0001)$. The risk of the composite renal endpoint was also reduced (hazard ratio $0.62 ; 95 \% \mathrm{CI}$ : $0.43-0.90 ; p=0.013)$. A more modest, but significant $13 \%$ reduction in all-cause death (hazard ratio 0.87 ; 95\% CI: $0.77-0.98 ; \mathrm{p}=0.018)$ and a $14 \%$ reduction in CV death (hazard ratio 0.86; 95\% CI: 0.76 - 0.98; $\mathrm{p}=0.027$ ) was computed. No heterogeneity of the treatment effects was found in any of these endpoints. Treatment effects were consistent for subgroups, based on age, sex, diabetes, treatment with an angiotensin receptor neprilysine inhibitor (ARNI) and baseline eGFR, but treatment-by-subgroup interactions were found for NYHA functional class, race and region. The hazard ratio for patients with NYHA class III - IV (hazard ratio $0.87 ; 95 \% \mathrm{CI}: 0.75-1.01 ; \mathrm{p}=0.064$ ) was significantly lower from that of patients with NYHA class II (hazard ratio 0.67; 95\% CI 0.59 - 0.76; $\mathrm{p}<0.0001$ ), with a $\mathrm{p}$ for interaction of 0.0087 [58]. These findings suggest that the inconsistent results regarding CV mortality in patients treated with either dapagliflozin or empagliflozin can stem from the lower magnitude of effect on this particular outcome along with the possible different effect in various disease states.

These two landmark trials have had a major impact for clinical practice and both ESC and ACC have updated their recommendation on the treatment of patients with HFrEF. Therefore, currently, dapagliflozin and empagliflozin were repurposed and are recommended to reduce the combined risk of HF hospitalization and $\mathrm{CV}$ death in symptomatic patients with HFrEF, already receiving guideline-directed optimal therapy, regardless of the presence of T2DM [24, 41]. Several trials investigating the role of SGLT2i in HF with preserved ejection fraction are awaited $[1,52]$.

\section{Conclusions}

Sodium-glucose co-transporter-2 inhibitors have been initially developed only as glucose-lowering drugs, however they have expanded far beyond this purpose after several large clinical trials have shown impressive reduction in major cardiovascular outcomes. Furthermore, dapagliflozin and empagliflozin significantly lowered the risk of HF hospitalization and CV death in patients with HFrEF even in the absence of T2DM, with no serious adverse events. The cardioprotective mechanisms of the SGLT2i, even though still incompletely understood, include an association between improvement in cardiac pre- and after-load, prevention of cardiac remodelling, direct cardiac effects with improved cardiac energetics and ion handling, anti-inflammatory effects, and anti-fibrotic effects. Therefore, both mechanistic insights as well as clinic trial data have shifted SGLT2i classification from only anti-hyperglicaemic drugs to potent HF treatment drugs.

\section{Conflict of interest}

The authors declare no conflict of interest.

\section{References}

1. Anker SD, Butler J, Filippatos G, Shahzeb Khan M, Ferreira JP, Bocchi E, Böhm M, Brunner-La Rocca HP, Choi DJ, Chopra V, Chuquiure E, Giannetti N, Gomez-Mesa JE, Janssens S, Januzzi JL, GonzalezJuanatey JR, Merkely B, Nicholls SJ, Perrone SV, Piña IL, Ponikowski P, Senni M, Seronde MF, Sim D, Spinar J, Squire I, Taddei S, Tsutsui H, Verma S, Vinereanu D, Zhang J, Jamal W, Schnaidt S, Schnee JM, Brueckmann M, Pocock SJ, Zannad F, Packer M, Baseline characteristics of patients with heart failure with preserved ejection fraction in the EMPERORPreserved trial. Eur J Heart Fail, 2020; 22(12): 2383-2392.

2. Baartscheer A, Schumacher CA, Wüst RC, Fiolet JW, Stienen GJ, Coronel R, Zuurbier CJ, Empagliflozin decreases myocardial cytoplasmic $\mathrm{Na}(+)$ through inhibition of the cardiac $\mathrm{Na}(+) / \mathrm{H}(+)$ exchanger in rats and rabbits. Diabetologia, 2017; 60(3): 568-573.

3. Bakris GL, Fonseca VA, Sharma K, Wright EM, Renal sodium-glucose transport: role in diabetes mellitus and potential clinical implications. Kidney Int., 2009; 75(12): 1272-1277.

4. Brown AJM, Gandy S, McCrimmon R, Houston JG, Struthers AD, Lang CC, A randomized controlled trial of dapagliflozin on left ventricular hypertrophy in people with type two diabetes: the DAPA-LVH trial. Eur Heart J., 2020; 41(36): 3421-3432.

5. Cannon CP, Pratley R, Dagogo-Jack S, Mancuso J, Huyck S, Masiukiewicz U, Charbonnel B, Frederich R, Gallo S, Cosentino F, Shih WJ, Gantz I, Terra SG, Cherney DZI, McGuire DK, Cardiovascular outcomes with ertugliflozin in type 2 diabetes. $N$ Engl $\mathrm{J}$ Med., 2020; 383(15): 1425-1435.

6. de Leeuw AE, de Boer RA, Sodium-glucose cotransporter 2 inhibition: cardioprotection by treating diabetes-a translational viewpoint explaining its potential salutary effects. Eur Heart J Cardiovasc Pharmacother., 2016; 2(4): 244-255.

7. Ehrenkranz JR, Lewis NG, Kahn CR, Roth J, Phlorizin: a review. Diabetes Metab Res Rev., 2005; 21(1): 31-38.

8. García-Ropero Á, Vargas-Delgado AP, Santos-Gallego CG, Inhibition of sodium glucose cotransporters improves cardiac performance. Int J Mol Sci., 2019; 20(13): 3289: 1-13.

9. Hallow KM, Helmlinger G, Greasley PJ, McMurray JJV, Boulton DW, Why do SGLT2 inhibitors reduce heart failure hospitalization? A differential volume regulation hypothesis. Diabetes Obes Metab., 2018; 20(3): 479-487. 
FARMACIA, 2021, Vol. 69, 5

10. Iacobellis G, Gra-Menendez S, Effects of dapagliflozin on epicardial fat thickness in patients with type 2 diabetes and obesity. Obesity, 2020; 28(6): 1068-1074.

11. Inzucchi SE, Zinman B, Fitchett D, Wanner C, Ferrannini E, Schumacher M, Schmoor C, Ohneberg K, Johansen OE, George JT, Hantel S, Bluhmki E, Lachin JM, How Does Empagliflozin reduce cardiovascular mortality? Insights from a mediation analysis of the EMPA-REG OUTCOME Trial. Diabetes Care, 2018; 41(2): 356-363.

12. Jarcho JA, More evidence for SGLT2 inhibitors in heart failure. New Engl J Med., 2020; 383(15): 14811482.

13. Jiang K, Xu Y, Wang D, Chen F, Tu Z, Qian J, Xu S, $\mathrm{Xu} \mathrm{Y,} \mathrm{Hwa} \mathrm{J,} \mathrm{Li} \mathrm{J,} \mathrm{Shang} \mathrm{H,} \mathrm{Cardioprotective}$ mechanism of SGLT2 inhibitor against myocardial infarction is through reduction of autosis. Protein Cell, 2021; online ahead of print.

14. Karg MV, Bosch A, Kannenkeril D, Striepe K, Ott C, Schneider MP, Boemke-Zelch F, Linz P, Nagel AM, Titze J, Uder M, Schmieder RE, SGLT-2inhibition with dapagliflozin reduces tissue sodium content: a randomised controlled trial. Cardiovascular Diabetol., 2018; 17(1): 5: 1-8.

15. Kario K, Okada K, Kato M, Nishizawa M, Yoshida T, Asano T, Uchiyama K, Niijima Y, Katsuya T, Urata H, Osuga JI, Fujiwara T, Yamazaki S, Tomitani N, Kanegae H, 24-Hour Blood Pressure-Lowering Effect of an SGLT-2 inhibitor in patients with diabetes and uncontrolled nocturnal hypertension: Results from the randomized, placebo-controlled SACRA Study. Circulation, 2018; 139(18): 2089-2097.

16. Karmazyn M, Sostaric JV, Gan XT, The myocardial $\mathrm{Na}+\mathrm{H}+$ exchanger: a potential therapeutic target for the prevention of myocardial ischaemic and reperfusion injury and attenuation of postinfarction heart failure. Drugs, 2001; 61(3): 375-389.

17. Kaufman M, Guglin M, Uric acid in heart failure: a biomarker or therapeutic target?. Heart Fail Rev., 2013; 18(2): 177-186.

18. Koepsell H, The Na+-D-glucose cotransporters SGLT1 and SGLT2 are targets for the treatment of diabetes and cancer. Pharmacol Ther., 2017; 170: 148-165.

19. Komoroski B, Vachharajani N, Boulton D, Kornhauser D, Geraldes M, Li L, Pfister M, Dapagliflozin, a novel SGLT2 inhibitor, induces dose-dependent glucosuria in healthy subjects. Clin Pharmacol Ther., 2009; 85(5): 520-526.

20. Kshirsagar RP, Kulkarni AA, Chouthe RS, Pathan SK, Une HD, Reddy GB, Diwan PV, Ansari SA, Sangshetti JN, SGLT inhibitors as antidiabetic agents: a comprehensive review. RSC Advances, 2020; 10(3): 1733-1756.

21. Lee MMY, Brooksbank KJM, Wetherall K, Mangion K, Roditi G, Campbell RT, Berry C, Chong V, Coyle L, Docherty KF, Dreisbach JG, Labinjoh C, Lang NN, Lennie V, McConnachie A, Murphy CL, Petrie CJ, Petrie JR, Speirits IA, Sourbron S, Welsh P, Woodward R, Radjenovic A, Mark PB, McMurray JJV, Jhund PS, Petrie MC, Sattar N, Effect of empagliflozin on left ventricular volumes in patients with type 2 diabetes, or prediabetes, and heart failure with reduced ejection fraction (SUGAR-DM-HF). Circulation, 2021; 143(6): 516-525.
22. Lopaschuk GD, Verma S, Mechanisms of cardiovascular benefits of sodium glucose co-transporter 2 (SGLT2) inhibitors: A State-of-the-Art Review. J Am Coll Cardiol: Basic Trans Sci., 2020; 5(6): 632-644.

23. Maack C, Lehrke M, Backs J, Heinzel FR, Hulot JS, Marx N, Paulus WJ, Rossignol P, Taegtmeyer H, Bauersachs J, Bayes-Genis A, Brutsaert D, Bugger H, Clarke K, Cosentino F, De Keulenaer G, Dei Cas A, González A, Huelsmann M, Iaccarino G, Lunde IG, Lyon AR, Pollesello P, Rena G, Riksen NP, Rosano G, Staels B, van Laake LW, Wanner C, Farmakis D, Filippatos G, Ruschitzka F, Seferovic P, de Boer RA, Heymans S, Heart failure and diabetes: metabolic alterations and therapeutic interventions: a state-ofthe-art review from the Translational Research Committee of the Heart Failure Association-European Society of Cardiology. Eur Heart J., 2018; 39(48): 4243-4254.

24. Maddox TM, Januzzi JL, Allen LA, Breathett K, Butler J, Davis LL, Fonarow GC, Ibrahim NE, Lindenfeld J, Masoudi FA, Motiwala SR, Oliveros E, Patterson JH, Walsh MN, Wasserman A, Yancy CW, Youmans QR, 2021 Update to the 2017 ACC Expert consensus decision pathway for optimization of heart failure treatment: Answers to 10 pivotal issues about heart failure with reduced ejection fraction. $\mathrm{J} \mathrm{Am} \mathrm{Coll}$ Cardiol., 2021; 77(6): 772-810.

25. Manoj A, Das S, Kunnath Ramachandran A, Alex AT, Joseph A, SGLT2 inhibitors, an accomplished development in field of medicinal chemistry: an extensive review. Future Med Chem., 2020; 12(21): 1961-1990.

26. Mazer CD, Hare GMT, Connelly PW, Gilbert RE, Shehata N, Quan A, Teoh H, Leiter LA, Zinman B, Jüni P, Zuo F, Mistry N, Thorpe KE, Goldenberg RM, Yan AT, Connelly KA, Verma S, Effect of empagliflozin on erythropoietin levels, iron stores, and red blood cell morphology in patients with type 2 diabetes mellitus and coronary artery disease. Circulation, 2020; 141(8): 704-707.

27. McMurray JJV, Solomon SD, Inzucchi SE, Køber L, Kosiborod MN, Martinez FA, Ponikowski P, Sabatine MS, Anand IS, Bělohlávek J, Böhm M, Chiang C-E, Chopra VK, de Boer RA, Desai AS, Diez M, Drozdz J, Dukát A, Ge J, Howlett JG, Katova T, Kitakaze M, Ljungman CEA, Merkely B, Nicolau JC, O'Meara E, Petrie MC, Vinh PN, Schou M, Tereshchenko S, Verma S, Held C, DeMets DL, Docherty KF, Jhund PS, Bengtsson O, Sjöstrand M, Langkilde AM, Dapagliflozin in patients with heart failure and reduced ejection fraction. New Engl J Med., 2019; 381(21): 1995-2008.

28. Merovci A, Solis-Herrera C, Daniele G, Eldor R, Fiorentino TV, Tripathy D, Xiong J, Perez Z, Norton L, Abdul-Ghani MA, DeFronzo RA, Dapagliflozin improves muscle insulin sensitivity but enhances endogenous glucose production. J Clin Invest., 2014; 124(2): 509-514.

29. Mustroph J, Wagemann O, Lücht CM, Trum M, Hammer KP, Sag CM, Lebek S, Tarnowski D, Reinders J, Perbellini F, Terracciano C, Schmid C, Schopka S, Hilker M, Zausig Y, Pabel S, Sossalla ST, Schweda F, Maier LS, Wagner S, Empagliflozin reduces $\mathrm{Ca} /$ calmodulin-dependent kinase II activity in isolated 
FARMACIA, 2021, Vol. 69, 5

ventricular cardiomyocytes. ESC Heart Failure, 2018; 5(4): 642-648.

30. Neal B, Perkovic V, Mahaffey KW, de Zeeuw D, Fulcher G, Erondu N, Shaw W, Law G, Desai M, Matthews DR, Canagliflozin and cardiovascular and renal events in type 2 diabetes. New Engl J Med., 2017; 377(7): 644-657.

31. Nikolic M, Zivkovic V, Jovic JJ, Sretenovic J, Davidovic G, Simovic S, Djokovic D, Muric N, Bolevich S, Jakovljevic V, SGLT2 inhibitors: a focus on cardiac benefits and potential mechanisms. Heart Fail Rev., 2021; (online ahead of print).

32. Packer M, Anker SD, Butler J, Filippatos G, Pocock SJ, Carson P, Januzzi J, Verma S, Tsutsui H, Jamal W, Kimura K, Schnee J, Zeller C, Cotton D, Bocchi E, Böhm M, Choi DJ, Chopra V, Chuquiure E, Giannetti N, Janssens S, Zhang J, Gonzalez Juanatey JR, Kaul S, Brunner-La Rocca H-P, Merkely B, Nicholls SJ, Perrone S, Pina I, Ponikowski P, Sattar N, Senni M, Seronde MF, Spinar J, Squire I, Taddei S, Wanner C, Zannad F, Cardiovascular and renal outcomes with empagliflozin in heart failure. New Engl J Med., 2020; 383(15): 1413-1424.

33. Perkovic V, Jardine MJ, Neal B, Bompoint S, Heerspink HJL, Charytan DM, Edwards R, Agarwal R, Bakris G, Bull S, Cannon CP, Capuano G, Chu P-L, de Zeeuw $\mathrm{D}$, Greene T, Levin A, Pollock C, Wheeler DC, Yavin Y, Zhang H, Zinman B, Meininger G, Brenner BM, Mahaffey KW, Canagliflozin and renal outcomes in type 2 diabetes and nephropathy. New Engl J Med., 2019; 380(24): 2295-2306.

34. Powell DR, Smith M, Greer J, Harris A, Zhao S, DaCosta C, Mseeh F, Shadoan MK, Sands A, Zambrowicz B, Ding ZM, LX4211 increases serum glucagon-like peptide 1 and peptide YY levels by reducing sodium/glucose cotransporter 1 (SGLT1)mediated absorption of intestinal glucose. J Pharmacol Exp Ther., 2013; 345(2): 250-259.

35. Rieg T, Vallon V, Development of SGLT1 and SGLT2 inhibitors. Diabetologia, 2018; 61(10): 2079-2086.

36. Santos-Gallego CG, Requena-Ibanez JA, San Antonio R, Ishikawa K, Watanabe S, Picatoste B, Flores E, Garcia-Ropero A, Sanz J, Hajjar RJ, Fuster V, Badimon JJ, Empagliflozin ameliorates adverse left ventricular remodeling in nondiabetic heart failure by enhancing myocardial energetics. J Am Coll Cardiol., 2019; 73(15): 1931-1944.

37. Sato T, Aizawa Y, Yuasa S, Kishi S, Fuse K, Fujita S, Ikeda Y, Kitazawa H, Takahashi M, Sato M, Okabe M, The effect of dapagliflozin treatment on epicardial adipose tissue volume. Cardiovasc Diabetol., 2018; 17(1): 6: 1-9.

38. Scheen AJ, Beneficial effects of SGLT2 inhibitors on fatty liver in type 2 diabetes: A common comorbidity associated with severe complications. Diabetes Metab., 2019; 45(3): 213-223.

39. Scheen AJ, Pharmacokinetics, pharmacodynamics and clinical use of SGLT2 inhibitors in patients with type 2 diabetes mellitus and chronic kidney disease. Clin Pharmacokinet., 2015; 54(7): 691-708.

40. Schubert M, Hansen S, Leefmann J, Guan K, Repurposing antidiabetic drugs for cardiovascular disease. Front Physiol., 2020; 11(1168): 568632: 1-20.
41. Seferović PM, Fragasso G, Petrie M, Mullens W, Ferrari R, Thum T, Bauersachs J, Anker SD, Ray R, Çavuşoğlu Y, Polovina M, Metra M, Ambrosio G, Prasad K, Seferović J, Jhund PS, Dattilo G, Piepoli M, Moura B, Chioncel O, Ben Gal T, Heymans S, Jaarsma T, Hill L, Lopatin Y, Lyon AR, Ponikowski $\mathrm{P}$, Lainščak M, Jankowska E, Mueller C, Cosentino F, Lund LH, Filippatos GS, Ruschitzka F, Coats AJS, Rosano GMC, Heart Failure Association of the European Society of Cardiology update on sodiumglucose co-transporter 2 inhibitors in heart failure. Eur J Heart Fail., 2020; 22(11): 1984-1986.

42. Sha S, Devineni D, Ghosh A, Polidori D, Chien S, Wexler D, Shalayda K, Demarest K, Rothenberg P, Canagliflozin, a novel inhibitor of sodium glucose cotransporter 2, dose dependently reduces calculated renal threshold for glucose excretion and increases urinary glucose excretion in healthy subjects. Diabetes Obes Metab., 2011; 13(7): 669-672.

43. Solini A, Giannini L, Seghieri M, Vitolo E, Taddei S, Ghiadoni L, Bruno RM, Dapagliflozin acutely improves endothelial dysfunction, reduces aortic stiffness and renal resistive index in type 2 diabetic patients: a pilot study. Cardiovasc Diabetol., 2017; 16(1): 138: 1-9.

44. Song P, Onishi A, Koepsell H, Vallon V, Sodium glucose cotransporter SGLT1 as a therapeutic target in diabetes mellitus. Expert Opin Ther Targets, 2016; 20(9): 1109-1125.

45. Tikkanen I, Chilton R, Johansen OE, Potential role of sodium glucose cotransporter 2 inhibitors in the treatment of hypertension. Curr Opin Nephrol Hypertens., 2016; 25(2): 81-86.

46. Uthman L, Baartscheer A, Bleijlevens B, Schumacher CA, Fiolet JWT, Koeman A, Jancev M, Hollmann MW, Weber NC, Coronel R, Zuurbier CJ, Class effects of SGLT2 inhibitors in mouse cardiomyocytes and hearts: inhibition of $\mathrm{Na}^{+} / \mathrm{H}^{+}$exchanger, lowering of cytosolic $\mathrm{Na}^{+}$and vasodilation. Diabetologia, 2018; 61(3): 722-726.

47. Uthman L, Nederlof R, Eerbeek O, Baartscheer A, Schumacher C, Buchholtz N, Hollmann MW, Coronel $\mathrm{R}$, Weber NC, Zuurbier CJ, Delayed ischaemic contracture onset by empagliflozin associates with NHE1 inhibition and is dependent on insulin in isolated mouse hearts. Cardiovasc Res., 2019; 115(10): 15331545.

48. Vallon V, Thomson SC, Targeting renal glucose reabsorption to treat hyperglycaemia: the pleiotropic effects of SGLT2 inhibition. Diabetologia, 2017; 60(2): 215-225.

49. Verma S, Mazer CD, Yan AT, Mason T, Garg V, Teoh H, Zuo F, Quan A, Farkouh ME, Fitchett DH, Goodman SG, Goldenberg RM, Al-Omran M, Gilbert RE, Bhatt DL, Leiter LA, Jüni P, Zinman B, Connelly KA, Effect of empagliflozin on left ventricular mass in patients with type 2 diabetes mellitus and coronary artery disease. Circulation, 2019; 140(21): 1693-1702.

50. Verma S, McMurray JJV, SGLT2 inhibitors and mechanisms of cardiovascular benefit: a state-of-theart review. Diabetologia, 2018; 61(10): 2108-2117.

51. White JR, Apple Trees to Sodium Glucose CoTransporter Inhibitors: A Review of SGLT2 Inhibition. Clinical Diabetes, 2010; 28(1): 5-10. 
52. Williams DM, Evans M, Dapagliflozin for Heart Failure with Preserved Ejection Fraction: Will the DELIVER Study Deliver?. Diabetes Ther., 2020; 11(10): 2207-2219.

53. Williams DM, Nawaz A, Evans M, Sodium-glucose co-transporter 2 (SGLT2) inhibitors: Are they all the same? A narrative review of cardiovascular outcome trials. Diabetes Ther., 2021; 12(1): 55-70.

54. Wiviott SD, Raz I, Bonaca MP, Mosenzon O, Kato ET, Cahn A, Silverman MG, Zelniker TA, Kuder JF, Murphy SA, Bhatt DL, Leiter LA, McGuire DK, Wilding JPH, Ruff CT, Gause-Nilsson IAM, Fredriksson M, Johansson PA, Langkilde AM, Sabatine MS, Dapagliflozin and cardiovascular outcomes in type 2 diabetes. New Engl J Med., 2018; 380(4): 347-357.

55. Wojcik C, Warden BA, Mechanisms and evidence for heart failure benefits from SGLT2 inhibitors. Curr Cardiol Rep., 2019; 21(10): 130: 1-14.

56. Ye Y, Bajaj M, Yang H-C, Perez-Polo JR, Birnbaum Y, SGLT-2 Inhibition with Dapagliflozin reduces the activation of the Nlrp3/ASC inflammasome and attenuates the development of diabetic cardiomyopathy in mice with type 2 diabetes. Further augmentation of the effects with saxagliptin, a DPP4 Inhibitor. Cardiovasc. Drugs Ther., 2017; 31(2): 119-132.

57. Zambrowicz B, Freiman J, Brown PM, Frazier KS, Turnage A, Bronner J, Ruff D, Shadoan M, Banks
P, Mseeh F, Rawlins DB, Goodwin NC, Mabon R, Harrison BA, Wilson A, Sands A, Powell DR, LX4211, a dual SGLT1/SGLT2 inhibitor, improved glycemic control in patients with type 2 diabetes in a randomized, placebo-controlled trial. Clin Pharmacol Ther., 2012; 92(2): 158-169.

58. Zannad F, Ferreira JP, Pocock SJ, Anker SD, Butler J, Filippatos G, Brueckmann M, Ofstad AP, Pfarr E, Jamal W, Packer M, SGLT2 inhibitors in patients with heart failure with reduced ejection fraction: a metaanalysis of the EMPEROR-Reduced and DAPA-HF trials. Lancet, 2020; 396(10254): 819-829.

59. Zelniker TA, Wiviott SD, Raz I, Im K, Goodrich EL, Bonaca MP, Mosenzon O, Kato ET, Cahn A, Furtado RHM, Bhatt DL, Leiter LA, McGuire DK, Wilding JPH, Sabatine MS, SGLT2 inhibitors for primary and secondary prevention of cardiovascular and renal outcomes in type 2 diabetes: a systematic review and meta-analysis of cardiovascular outcome trials. Lancet, 2019; 393(10166): 31-39.

60. Zinman B, Wanner C, Lachin JM, Fitchett D, Bluhmki E, Hantel S, Mattheus M, Devins T, Johansen OE, Woerle HJ, Broedl UC, Inzucchi SE, Empagliflozin, cardiovascular outcomes, and mortality in type 2 diabetes. New Engl J Med., 2015; 373(22): 2117-2128. 